\title{
Verschillen in diversificatie door coöperaties en vennootschappen
}

Prof. Dr. G.W.J. Hendrikse en Dr. A.A.C.J. van Oijen

\section{Inleiding}

Een derde deel van de voedselproductie in de wereld wordt voortgebracht via coöperaties (Pattison, 2000). Deze constatering geeft aanleiding tot twee vragen. In de eerste plaats is het van belang om te weten of de beheersstructuur coöperatie leidt tot efficiënte voedselproductie. In de tweede plaats is het interessant om te weten waarom niet alle productie van voedsel in coöperaties plaatsvindt.

Dit artikel vormt een empirische aanzet tot het beantwoorden van de eerste vraag door de diversificatiestrategie van coöperaties en vennootschappen met elkaar te vergelijken. Het coëxisteren van beide organisatievormen in vele bedrijfstakken biedt daartoe verscheidene mogelijkheden. De gevolgen van de keuze van beheersstructuur voor de diversificatiestrategie worden empirisch nagegaan in drie sectoren (landbouw/voedingsmiddelen, handel en financiële dienstverlening) in Nederland. Hendrikse (1998) presenteert met betrekking tot de tweede vraag gegevens die aangeven dat in de meeste land- en tuinbouwsectoren zowel coöperaties als vennootschappen opereren en oppert hiervoor een verklaring.

Een beheersstructuur specificeert enerzijds wie formeel de beslissingsrechten in handen heeft en anderzijds de wijze waarop de opbrengsten en kosten worden verdeeld (Hansmann, 1996). Beheersstructuren kunnen van elkaar worden onderscheiden op basis van wie de beslissingsrechten in handen heeft. De kapitaalverschaffers c.q. aandeelhouders zijn de eigenaren van de onderneming in een vennootschap. In een afzet-

Prof. Dr. G.W.J. Hendrikse is hoogleraar Methodologie in de faculteit Bedrijfskunde aan de Erasmus Universiteit Rotterdam.

Dr. A.A.C.J. van Oijen is Universitair Hoofddocent Organisatie en Strategie Economische Wetenschappen aan de Katholieke Universiteit Brabant. coöperatie, waarvan de land- en tuinbouwcoöperatie een voorbeeld is, hebben de toeleveranciers c.q. boeren de formele beslissingsautoriteit over deze beslissingen. Hiermee vergelijkbaar is dat in een werknemerscoöperatie de werknemers deze beslissingen nemen (arbeiderszelfbestuur), terwijl in een inkoopcoöperatie de afnemers het voor het zeggen hebben.

Productdiversificatie houdt in het betreden van voor het betreffende bedrijf nieuwe bedrijfstakken. Een bedrijf wordt gezien als gediversificeerd wanneer ze tegelijkertijd in meerdere bedrijfstakken actief is (Pitts and Hopkins, 1982). Doorgaans wordt onderscheid gemaakt tussen gerelateerde en ongerelateerde diversificatie (Van Oijen, 1997). Gerelateerde diversificatie betreft het actief worden in een voor het bedrijf nieuwe bedrijfstak die verbonden is aan de bestaande activiteiten van het bedrijf door middel van overeenkomsten in een of meerdere activiteiten van de waardeketen (zie Porter, 1985). De overeenkomsten houden normaal gesproken verband met de productie, marketing of technologie. Ongerelateerde diversificatie, ofwel conglomeratie, houdt in het actief worden in een voor het bedrijf nieuwe bedrijfstak die geen significante overeenkomsten met de bestaande activiteiten vertoont.

Lins en Servaes (1999) hebben empirisch een relatie gevonden tussen het effect van diversificatiebeleid op de waarde van de onderneming en de institutionele structuur van een land. De institutionele structuur van een land is gemeten op basis van de concentratie van eigendom en de structuur van industriële groepen. Zij concluderen dat 'evidence supports the notion that differences in corporate governance matter' (p. 2237). Kamshad (1994) heeft empirisch geen significant verschil tussen de diversificatiestrategie van naamloze vennootschappen (NV's) en werknemercoöperaties in Frankrijk kunnen vaststellen. In dit artikel worden vennootschappen en coöperaties in Nederland met elkaar vergeleken.

Het artikel is als volgt opgebouwd. De volgen- 
de paragraaf geeft een overzicht van de theorieën ter verklaring van diversificatie die gangbaar zijn in de literatuur. De daaropvolgende paragraaf gaat in op de verschillen tussen de beheersstructuren vennootschap en coöperatie en de verwachte consequenties daarvan voor de diversificatiestrategie. Deze paragraaf bevat tevens de hypothesen van dit onderzoek. De volgende twee paragrafen zijn gewijd aan de opzet en de gevonden resultaten van het empirische onderzoek. De samenvatting en conclusies sluiten het artikel af.

\section{Perspectieven op diversificatie}

In de literatuur is geen geïntegreerd theoretisch kader beschikbaar dat diversificatie verklaart (Hoskisson en Hitt, 1990). Bijdragen aan de verklaring van diversificatie worden geleverd vanuit vijf perspectieven, te weten marktmacht, motieven, contingenties, hulpbronnen en voordelen. We gaan kort in op elk perspectief.

\section{Marktmacht}

Volgens dit perspectief diversificeren ondernemingen omdat gediversificeerde ondernemingen in staat zijn marktmacht uit te oefenen (Montgomery, 1994; Palepu, 1985; Ramanujam en Varadarajan, 1989). Zij hebben toegang tot een scala aan instrumenten, zoals kruissubsidiëring, plunderend prijzen, reciprociteit bij aan- en verkoop, creatie van toetredingsbarrières en wederzijdse verdraagzaamheid. Kruissubsidiëring, ook wel aangeduid als deep pockets, houdt in het gebruik van winsten die verdiend zijn met de ene productsoort voor financiële ondersteuning van een andere productsoort. Plunderend prijzen, ofwel predatory pricing, is een vergelijkbaar instrument. Het betekent de aanwending van inkomsten die verdiend zijn in bepaalde productdivisies voor de verlaging van de prijzen die berekend worden door andere divisies. Reciprociteit bij aan- en verkoop treedt op als klanten tegelijkertijd leveranciers van een onderneming zijn. De onderneming kan dan afspraken maken in de zin van 'als jij van mij koopt, dan koop ik van jou' (Williamson, 1975). De kans hierop is groter als ondernemingen meer gediversificeerd zijn. Het gevolg is dat markten gesloten worden voor ongediversificeerde ondernemingen. Dit is tevens de essentie van het als vierde genoemde instrument. Door diversificatie worden toetredingsbarrières gecreëerd, omdat toetreders gedwongen zijn om tegelijkertijd diverse bedrijfstakken te betreden. Wederzijdse verdraagzaamheid, ofwel mutual forbearance, ten slotte, impliceert erkenning door gediversificeerde ondernemingen die elkaar in meerdere markten van de onderlinge afhankelijkheid tegenkomen en daarom de keuze hebben voor minder felle onderlinge concurrentie. Met behulp van elk van deze instrumenten kunnen gediversificeerde ondernemingen de concurrentie verminderen en daardoor hun winstgevendheid vergroten. Dit hoeft natuurlijk niet gunstig te zijn voor de economie of welvaart als geheel.

\section{Motieven}

Uitgaande van dit perspectief diversificeren ondernemingen omdat hun leidinggevenden daarvoor persoonlijke motieven hebben. Het perspectief is geworteld in de agency-theorie. Volgens deze theorie kan tussen de eigenaren en leidinggevenden van een onderneming een belangenconflict inzake de uitkering van de vrije kasstroom bestaan. Jensen (1986) definieert de vrije kasstroom als de kasstroom die uitstijgt boven de kasstroom die benodigd is om alle projecten met een positieve netto contante waarde te financieren. Uitkering van de vrije kasstroom aan de eigenaren is in hun belang. Leidinggevenden zijn echter afkerig van uitkering, omdat deze de middelen en dus de macht waarover ze beschikken, vermindert. Leidinggevenden besteden de vrije kasstroom daarom liever aan verliesgevende projecten, waaronder bijvoorbeeld diversificatie. Voor diversificatie wordt gekozen uit imperialistische overwegingen (empire building, volgens Montgomery, 1994). Verder kunnen leidinggevenden hun beloning verhogen door diversificatie, want uit onderzoek blijkt dat de omvang van ondernemingen en de beloning van hun topmanagers sterk positief gecorreleerd zijn (Tosi en Gomez-Mejia, 1989). De omvang neemt toe als gevolg van diversificatie. Ten slotte kunnen leidinggevenden door middel van diversificatie het werkgelegenheidsrisico spreiden. Diversificatie wordt namelijk geacht de kans op een faillissement en daarmee verlies van werkgelegenheid te verminderen.

\section{Contingenties}

Het derde perspectief op diversificatie komt voort uit de strategische contingentietheorie van Venkatraman (1989). Volgens deze benadering vergroten ondernemingen hun prestaties door een goede afstemming van hun strategie op allerlei interne en externe contingenties of eventualiteiten. Ook een diversificatiestrategie kan een reactie zijn op diverse contingenties. Voorbeelden zijn mededingingswetgeving, marktfalen, slechte resultaten en onzekerheid in de traditionele activiteiten en risicoreductie. Mededingingswetgeving is gericht tegen te grote machtsconcentraties in bedrijfstakken. Ondernemingen die desondanks willen groeien, zullen dan andere bedrijfstakken moeten betreden en dus moeten diversificeren. Marktfalen 
impliceert dat bepaalde transacties beter binnen een onderneming gehouden kunnen worden dan via de markt verlopen, omdat de markt te hoge transactiekosten met zich meebrengt (Williamson, 1975). Het hoofdkantoor van een onderneming met een divisiestructuur wordt bijvoorbeeld geacht beter dan de externe vermogensmarkt in staat te zijn financiële middelen te alloceren naar winstgevende projecten. Dit kunnen projecten zijn die buiten de bestaande activiteiten van de onderneming liggen, hetgeen zou leiden tot diversificatie. Slechte resultaten in de traditionele activiteiten en onzekerheid ten aanzien van de in de toekomst te behalen resultaten kunnen ondernemingen ertoe aanzetten hun heil te zoeken in meer aantrekkelijke bedrijfstakken. Risicoreductie ten slotte houdt in dat gediversificeerde ondernemingen niet, zoals dat heet, alle eieren in een mandje stoppen (Amit en Livnat, 1988). Dit kan aantrekkelijk zijn voor hun managers, werknemers, leveranciers en afnemers en zelfs eigenaren (Hoskisson en Hitt, 1990; Montgomery, 1994).

\section{Hulpbronnen}

Volgens het vierde perspectief kunnen ondernemingen beschikken over een overcapaciteit in hulpbronnen of resources (Penrose, 1959). Soms kunnen de ongebruikte hulpbronnen worden verhuurd, verkocht of, in de vorm van dividenden, teruggegeven aan de eigenaren. In andere gevallen kunnen de hulpbronnen worden geherinvesteerd in de bestaande activiteiten. De ongebruikte hulpbronnen kunnen echter ook benut worden door ze in te zetten voor nieuwe activiteiten, ofwel door te diversificeren. De aard van de resources bepaalt de richting van de diversificatie (Chatterjee en Wernerfelt, 1991). Tastbare hulpbronnen, zoals een machinepark, en ontastbare hulpbronnen, zoals vaardigheden, zijn doorgaans niet breed inzetbaar en lenen zich daarom slechts voor gerelateerde diversificatie. Financiële hulpbronnen zijn breed inzetbaar en lenen zich derhalve ook voor ongerelateerde diversificatie. Vanuit de in de jaren negentig populair geworden resource-based view worden verschillende eisen gesteld waaraan hulpbronnen moeten voldoen voordat ze leiden tot duurzaam concurrentieel voordeel voor een onderneming (zie bijvoorbeeld Peteraf, 1993). Zij moeten bijvoorbeeld immobiel (dat wil zeggen, niet via de markt verhandelbaar), niet substitueerbaar en niet imiteerbaar zijn.

\section{Voordelen}

Het laatste perspectief houdt in dat ondernemingen diversificeren om voordelen te realiseren. Deze kunnen worden ingedeeld in twee categorieën: synergetische voordelen en financiële voordelen.
Synergetische voordelen zijn gebaseerd op het gezamenlijk gebruik van dezelfde niet-financiële hulpbronnen door meerdere divisies van een onderneming. Een nieuwe productietechnologie die ontwikkeld is in de ene divisie kan bijvoorbeeld overgedragen worden aan een andere divisie, waardoor kostenbesparingen of economies of scope gerealiseerd kunnen worden (Teece, 1982). Financiële voordelen berusten op een indirecte, financiële afhankelijkheid tussen divisies. Tot deze voordelen kunnen onder meer worden gerekend risicoreductie (Amit en Livnat, 1988) en de superieure allocatie van middelen en toezicht op de aanwending daarvan van de interne vermogensmarkt (Williamson, 1975).

De voordelen van diversificatie dienen de nadelen of kosten te overtreffen. Een belangrijke kostenpost wordt gevormd door de bureaucratische kosten (Jones en Hill, 1988). Gediversificeerde ondernemingen worden meestal bestuurd via een divisiestructuur. Hierin moet een beheerssysteem worden opgezet die de topmanagers voorziet van informatie over mogelijk kwalijk gedrag van de divisiemanagers. De hieraan verbonden kosten worden bureaucratische kosten genoemd. Andere belangrijke kosten van diversificatie zijn de verborgen kosten (Prahalad en Bettis, 1986). Deze worden veroorzaakt door onjuiste en trage beslissingen door topmanagement dat onvoldoende inzicht heeft in de diverse activiteiten van de onderneming.

\section{Theorie en hypothesen}

De vijf gangbare verklaringen van diversificatie, die in de voorgaande paragraaf behandeld zijn, bieden slechts beperkte aanknopingspunten voor het leggen van een verband tussen beheersstructuur en diversificatie. Natuurlijk zou de beheersstructuur toegevoegd kunnen worden als additionele contingentie aan de strategische contingentietheorie van Venkatraman (1989). Dan zal echter nog een theorie ontwikkeld moeten worden die duidelijk maakt hoe en waarom de onderscheiden beheersstructuren de diversificatiestrategie beïnvloeden. In deze paragraaf geven wij een aanzet tot deze theorie.

De aandeelhouders of verschaffers van het eigen vermogen zijn te beschouwen als de eigenaren van de onderneming in een vennootschap. $\mathrm{Zij}$ beslissen in principe over nieuwe investeringen en te gebruiken inputs. In een afzetcoöperatie beslissen de boeren hierover. Dit brengt meestal met zich mee dat elk lid in een afzetcoöperatie activa bezit in, en derhalve beslist over, twee fasen van de productiekolom. De boer beslist individueel over de investeringen op zijn boerderij en heeft 
de betreffende activa in bezit. Daarnaast is de eigendom over de activa in de volgende fase van de productiekolom, die worden aangewend om de oogst te verwerken, in handen van alle coöperatieleden gezamenlijk. Een land- en tuinbouwcoöperatie komt neer op voorwaartse integratie van vele boeren gezamenlijk in de verwerkende fase van de productiekolom.

Dit verschil tussen de beheersstructuren vennootschap en coöperatie werkt in vele kenmerken van deze organisaties door (Hendrikse en Bijman, 2001 en Hendrikse en Veerman, 1997, 2001a en 2001b). In een afzetcoöperatie zijn de leden gezamenlijk eigenaar, dragen de leden zorg voor de financiering, is er sprake van een democratische besluitvormingsstructuur en worden grondstoffen van de leden betrokken. De aandeelhouders in een vennootschap zijn daarentegen individueel eigenaar, zij hebben het externe eigen vermogen ingebracht, de besluitvorming is autocratisch en grondstoffen worden van de beste leverancier betrokken.

Op een aantal aspecten van democratische besluitvorming zal nu kort worden ingegaan aan de hand van Hendrikse en Veerman (2001a). Democratische besluitvorming brengt het streven naar consensus met zich mee om alle leden bij de organisatie betrokken te houden. Dit heeft zowel voor- als nadelen. Aantrekkelijk is dat verschillende perspectieven en ervaringen in de besluitvorming kunnen worden gecombineerd en het besluitvormingsproces minder gevoelig is voor politieke activiteiten, omdat slechte voorstellen niet overleven. Een belangrijk nadeel is gelegen in het tijdrovende proces van consensus- en besluitvorming betreffende belangrijke beleidswijzigingen, zeker wanneer een directe relatie met de oorspronkelijke activiteiten van de coöperatie (en derhalve met de basisactiviteiten van de leden) moeilijk te leggen is.

De democratische besluitvormingsstructuur in coöperaties is niet alleen tijdrovend, maar kan ook leiden tot een tendens om nieuwe initiatieven te vermijden. Nieuwe initiatieven hebben namelijk niet voor alle leden dezelfde gevolgen. Het gebrek aan homogeniteit in het ledenbestand kan het bereiken van consensus over nieuwe initiatieven in de weg staan. Daarnaast versterkt de wijze van financieren de tendens tot het vermijden van nieuwe initiatieven. Overnames kunnen niet via extern eigen vermogen (aandelen) worden gefinancierd. Eigen vermogen dient intern te worden gegenereerd. Dit brengt problemen met zich mee als gevolg van de beperkte duur van het lidmaatschap van de leden. Opbrengsten tijdens het lidmaatschap dienen namelijk minstens zo hoog te zijn als opbrengsten elders. Interne financiering vereist dat de interne 'rate of return' op de activa van de coöperatie hoger dient te zijn dan die in een vennootschap wanneer de duur van het gemiddelde lidmaatschap korter is dan de terugverdienperiode van het project. Dit wordt het 'horizonprobleem' genoemd (Bonin, Jones en Putterman, 1993). De vergrijzing in coöperaties verergert dit probleem. Coöperaties die voornamelijk gebruikmaken van interne financiële middelen zullen derhalve onderinvesteren in vergelijking tot overeenkomstige vennootschappen wanneer de claims van individuele leden niet overdraagbaar zijn. Dit effect wordt verder versterkt door de voorwaarden waarop financiële middelen beschikbaar worden gesteld door externe partijen. De eigenschap van ledendominantie in een coöperatie houdt in dat de zeggenschap van externe eigenvermogensverschaffers dient te worden afgekocht. Hiervan is geen sprake in een vennootschap. De toewijzing van zeggenschap over investeringsbeslissingen aan aandeelhouders geeft aandeelhouders in een vennootschap het vertrouwen dat hun financiële middelen goed zullen worden aangewend.

Op basis van deze verschillen tussen de beheersstructuren vennootschap en coöperatie wordt verwacht dat vennootschappen meer diversificeren dan coöperaties, zowel gerelateerd als ongerelateerd. Deze conclusies zijn weergegeven in de volgende twee hypothesen.

\section{Hypothese 1: Vennootschappen kiezen voor meer gerelateerde diversificatie dan coöperaties.}

\section{Hypothese 2: Vennootschappen kiezen voor meer ongerelateerde diversificatie dan coöperaties.}

Consensus besluitvorming in coöperaties zal soepeler verlopen naarmate het ledenbestand homogener is. Coöperaties die zich richten op één activiteit, zoals de verwerking van zuivel, kennen een relatief homogeen ledenbestand. Diversificatie kan de homogeniteit ondermijnen. Een coöperatie die bijvoorbeeld naast zuivelproducten groente in blik gaat verkopen krijgt te maken met twee soorten leden c.q. toeleveranciers, te weten melkveehouders en akkerbouwers. Verdeling van de opbrengsten kan in deze situatie lastig worden. Vanwege de verwantschap tussen de activiteiten is het zinvol om bepaalde functies te bundelen. Zo zou de marketing en distributie van de producten tot op zekere hoogte gecombineerd kunnen worden, teneinde kosten te besparen. Een eenvoudige verdeelsleutel voor de verdeling van de opbrengsten, zoals het aantal aangeleverde liters van een bepaalde kwaliteit, kan echter niet meer toegepast worden. Moeizame onderhandelingen tussen de diverse categorieën van leden kunnen het 
gevolg zijn. Het toevoegen van een ongerelateerde activiteit, zoals het verkopen van verzekeringsproducten, vermindert dit probleem. Er zal veel minder sprake zijn van gecombineerde functies. Elke activiteit heeft opzichzelfstaande opbrengsten, die op betrekkelijk eenvoudige wijze over de betreffende categorieën van leden verdeeld kunnen worden. Bij vennootschappen zorgt gerelateerde diversificatie voor veel minder problemen. De aandeelhouders zijn homogeen, in die zin dat ze dezelfde soort middelen inbrengen. De winsten kunnen verdeeld worden naar rato van het vermogen dat ingebracht wordt. Daar komt nog bij dat aandeelhouders hun risico op eenvoudige wijze kunnen diversificeren door het aanhouden van een portefeuille aandelen. De welvaart van leden hangt daarentegen veel meer af van het wel en wee van de coöperatie waarvan zij lid zijn. $\mathrm{Zij}$ zijn daarom gebaat bij een coöperatie die investeert in activiteiten waarvan de rendementen weinig correleren, zodat de risico's gespreid worden. Ongerelateerde diversificatie draagt hier zorg voor. De verwachting is derhalve dat, in vergelijking tot een vennootschap, een coöperatie relatief meer diversificeert in ongerelateerde dan gerelateerde activiteiten. Dit is weergegeven in de derde hypothese.

Hypothese 3: Coöperaties diversificeren in vergelijking tot vennootschappen relatief meer in ongerelateerde diversificatie dan in gerelateerde diversificatie.

\section{Methoden}

\section{Data en steekproef}

De voor de toetsing van de hypothesen benodigde gegevens zijn vooral afkomstig uit REACH (Review and Analysis of Companies in Holland). REACH is een elektronische databank, die gegevens bevat van vele Nederlandse bedrijven. De gegevens zijn overwegend financieel van aard. Voor ons onderzoek is van belang dat daarnaast de rechtsvorm en de BIK-code(s) van elk bedrijf vermeld worden. BIK, ofwel BedrijfsIndeling Kamers van Koophandel, staat voor een systeem voor de classificatie van economische activiteiten. Het is vergelijkbaar met de, wellicht meer bekende, Amerikaanse SIC (Standard Industry Classification).

We hebben de coöperaties die deel uitmaken van de editie van REACH uit 1996 opgenomen in onze steekproef. Voor elke coöperatie hebben we de hoofdactiviteit bepaald. Deze is gebaseerd op de BIK-codes en de korte beschrijving van de activiteiten uit REACH. Indien laatstgenoemde niet opgenomen was in REACH hebben we gebruik gemaakt van alternatieve bronnen, zoals internet. Vervolgens hebben we een bijpassende vennootschap met dezelfde activiteit geselecteerd. Deze benadering stelde ons in staat te controleren voor bedrijfstakeffecten. Als meerdere vennootschappen beschikbaar waren, hebben we een willekeurige vennootschap gekozen.

De resulterende steekproef bevat 114 bedrijven, waaronder 57 coöperaties en 57 vennootschappen. De bedrijven kunnen toegewezen worden aan drie brede categorieën van activiteiten: landbouw- en voedingsmiddelenindustrie ( 58 bedrijven), financiële dienstverlening ( 34 bedrijven) en groot- en detailhandel (16 bedrijven). Daarnaast is er een kleine categorie overige bedrijven ( 6 bedrijven).

\section{Maatstaven}

Diversificatiestrategie

Voor de meting van de diversificatiestrategie hebben we de zogenaamde product-count-maatstaven van Wood (1971) gebruikt. Deze ongewogen maatstaven zijn minder verfijnd dan de veelvuldig gebruikte entropiemaatstaven (Jacquemin en Berry, 1979). Echter, ze zijn eenvoudig te berekenen en stellen geen hoge eisen aan de benodigde informatie (Lubatkin, Merchant en Srinivasin, 1993). In het bijzonder vereisen ze geen opsplitsing van de totale omzet van een bedrijf naar activiteitencodes. Een dergelijke opsplitsing zou in onze studie niet haalbaar zijn, omdat de meeste bedrijven uit onze steekproef de vereiste gegevens niet openbaar maken. Bovendien vinden Lubatkin et al. (1993) een hoge mate van overeenkomst tussen de strategische maatstaf van Rumelt (1974) en de product-count-maatstaven van Wood (1971), hetgeen validiteit van laatstgenoemde maatstaven suggereert.

Wood (1971) onderscheidt broad spectrum diversification (BSD) en narrow spectrum diversification (NSD). BSD is expansie naar een andere bedrijfstak waarbij het criterium een verschil tussen de eerste twee cijfers van de activiteitencodes is. NSD is expansie naar een bedrijfstak met een andere viercijferige activiteitencode, maar dezelfde eerste twee cijfers van de activiteitencode. BSD kan gezien worden als ongerelateerde diversificatie, terwijl NSD staat voor gerelateerde diversificatie (Ramanujam en Varadarajan, 1987). We hebben zowel BSD als NSD berekend op basis van de BIK-codes van elk bedrijf volgens REACH. Teneinde de normale verdeling beter te benaderen, hebben we zowel BSD als NSD logaritmisch getransformeerd. Dit leidde tot de variabelen LOGBSD respectievelijk LOGNSD.

Voor de toetsing van hypothese 3 is een variabele benodigd die iets zegt over de verhouding tussen gerelateerde en ongerelateerde diversifica- 
tie. Hiervoor hebben we gebruikgemaakt van een variant van de door Ramanujam en Varadarajan (1987) geïntroduceerde variabele MNSD.

Deze afkorting staat voor mean narrow spectrum diversity. MNSD wordt berekend als het aantal viercijferige activiteitencodes gedeeld door het aantal tweecijferige activiteitencodes van een bedrijf. Om de verhouding tussen gerelateerde en ongerelateerde diversificatie beter tot uitdrukking te brengen, hebben we de teller vervangen door NSD, onze maatstaf voor gerelateerde diversificatie. Ook hier hebben we de uitkomst logaritmisch getransformeerd om de normale verdeling beter te benaderen. De uiteindelijke variabele heet LOGMNSD.

\section{Rechtsvorm}

Voor de beheersstructuur, ofwel de rechtsvorm, van een bedrijf hebben we de dichotome variabele LEGALS gebruikt. LEGALS heeft een waarde van 0 voor coöperaties en een waarde 1 voor vennootschappen.

\section{Omvang}

Controleren voor omvang is zeer gebruikelijk in diversificatiestudies (Chatterjee en Wernerfelt, 1991). Een positieve correlatie kan verwacht worden tussen omvang en diversificatie. Bovendien kunnen vennootschappen groter zijn dan coöperaties. Zoals reeds eerder aangegeven, kennen vennootschappen bijvoorbeeld minder restricties ten aanzien van de financiering van expansie. Indien we niet voor omvang zouden controleren, dan zouden verschillen tussen de diversificatiestrategieën van vennootschappen en coöperaties geassocieerd kunnen worden met verschillen in de omvang, in plaats van de beheersstructuur. Gewoonlijk wordt de totale omzet van een bedrijf gebruikt als benadering van omvang (Nayyar, 1993). Wij hebben de totale omzet van een bedrijf in 1995 gebruikt. Om een meer normale verdeling te verkrijgen, hebben we LOGSALES, de log van de omzet, gebruikt.

\section{Statistische analyse}

Voor het toetsen van de hypothesen hebben we analyse van covariantie (ANCOVA) gebruikt. Drie analyses zijn uitgevoerd: een met LOGBSD als de afhankelijke variabele, een met LOGNSD als de afhankelijke variabele en een met LOGMNSD als afhankelijke variabele. In alle gevallen was de factor LEGALS en de covariaat LOGSALES. Het opnemen van LOGSALES als een covariaat impliceert het testen of de gemiddelde verschillen in diversificatiestrategie geassocieerd zijn met de beheersstructuur, na aanpassing voor verschillen in omvang.

\section{Resultaten}

Hypothese 1 voorspelde dat coöperaties minder gerelateerde diversificatie hebben dan vennootschappen. Hypothese 2 voorspelde hetzelfde, maar dan voor ongerelateerde diversificatie. Volgens hypothese 3 diversificeren coöperaties relatief meer ongerelateerd dan gerelateerd, in vergelijking met vennootschappen. Dat wil zeggen, de verhouding tussen gerelateerde en ongerelateerde diversificatie is voor coöperaties lager dan voor vennootschappen.

Tabel 1 toont de resultaten die verkregen zijn nadat de drie hypothesen getest zijn door het vergelijken van coöperaties met vennootschappen, controlerend voor de omvang. We hebben één vennootschap uitgesloten van de steekproef, aangezien deze een outlier bleek te zijn, zowel voor wat betreft de grootte als de diversificatiestrategie. Tabel 1 geeft ook enige beschrijvende statistieken. Aangemerkt dient te worden dat de groepsgemiddelden en standaardafwijkingen (tussen haakjes) niet gebaseerd zijn op de getransformeerde variabelen LOGBSD, LOGNSD EN LOGMNSD, maar op de ongetransformeerde variabelen, omdat deze eenvoudiger te interpreteren zijn.

De resultaten geven aan dat omvang (LOGSALES) een statistisch significante invloed op gerelateerde diversificatie (LOGNSD) en op de verhouding tussen gerelateerde en ongerelateerde diversificatie (LOGMNSD) heeft. Deze invloeden zijn positief. Tussen omvang en ongerelateerde diversificatie (LOGBSD) bestaat geen verband.

Het effect van de juridische structuur (LEGALS) is zeer significant, voor wat betreft gerelateerde en ongerelateerde diversificatie. Uit de gemiddelden blijkt dat, in het algemeen, vennootschappen actief zijn in 1.49 maal zoveel ongerelateerde bedrijfstakken als coöperaties. Het verschil is iets groter voor gerelateerde diversificatie. Vennootschappen zijn actief in 1.54 maal zoveel gerelateerde bedrijfstakken als coöperaties. Vennootschappen zijn derhalve meer gediversificeerd, zowel gerelateerd als ongerelateerd, dan coöperaties. Dit ondersteunt de eerste twee hypothesen. De resultaten zijn overigens stabiel in alle sectoren. Dat wil zeggen, in de landbouw- en voedingsmiddelenindustrie, de financiële dienstverlening, de groot- en detailhandel en de categorie overige zijn vennootschappen gemiddeld meer gediversificeerd dan coöperaties, zowel ongerelateerd als gerelateerd.

De gemiddelden lijken hypothese 3 te ondersteunen. Coöperaties worden inderdaad gekenmerkt door meer ongerelateerde diversificatie ten opzichte van gerelateerde diversificatie dan vennootschappen. Het verschil is echter niet statistisch significant. Dit patroon herhaalt zich in drie 
van de vier sectoren. Alleen in de financiële dienstverlening is de verhouding tussen gerelateerde en ongerelateerde diversificatie nagenoeg gelijk voor coöperaties en vennootschappen.

Tabel: ANCOVA resultaten

\begin{tabular}{|c|c|c|c|c|c|c|}
\hline & \multicolumn{2}{|c|}{$L O G B S D$} & \multicolumn{2}{|c|}{$L O G N S D$} & \multicolumn{2}{|c|}{ LOGMNSD } \\
\hline & $F$ & $p$ & $F$ & $p$ & $F$ & $p$ \\
\hline \multicolumn{7}{|l|}{$\begin{array}{l}\text { Factor voor } \\
\text { rechtsvorm: }\end{array}$} \\
\hline LEGALS & 19.08 & 0.00 & 8.90 & 0.00 & 0.04 & 0.84 \\
\hline \multicolumn{7}{|c|}{$\begin{array}{l}\text { Covariaat } \\
\text { voor omvang: }\end{array}$} \\
\hline LOGSALES & 0.08 & 0.77 & 13.81 & 0.00 & 9.06 & 0.00 \\
\hline \multicolumn{7}{|c|}{ Groepsgemiddelde: } \\
\hline$(\mathrm{N}=57)$ & \multicolumn{2}{|c|}{$1.28(0.53)$} & \multicolumn{2}{|c|}{$1.81(1.33)$} & \multicolumn{2}{|c|}{$1.44(0.88)$} \\
\hline \multicolumn{7}{|c|}{ Vennootschappen } \\
\hline$(\mathrm{N}=56)$ & \multicolumn{2}{|c|}{$1.91(0.98)$} & \multicolumn{2}{|c|}{$2.79(1.90)$} & \multicolumn{2}{|c|}{$1.87(1.67)$} \\
\hline
\end{tabular}

\section{Samenvatting en verder onderzoek}

In dit artikel zijn de gevolgen van de beheersstructuur voor de productdiversificatie onderzocht. In het bijzonder zijn hypothesen ontwikkeld inzake de verschillen tussen de diversificatiestrategieën van coöperaties en die van vennootschappen. Toetsing van deze hypothesen heeft plaatsgevonden op basis van een cross sectie onderzoek van 114 Nederlandse coöperaties en vennootschappen. De resultaten geven aan dat vennootschappen meer gediversificeerd zijn dan coöperaties, zowel gerelateerd als ongerelateerd. Omdat dit blijkt te gelden voor elke sector die wij onderscheiden hebben, kunnen we concluderen dat het gezegde 'Wat de boer niet kent, dat eet hij niet' niet alleen opgaat voor de agrarische wereld, maar ook voor leden van coöperaties in andere sectoren.

Toevoeging van de beheersstructuur aan de gangbare verklaringen van diversificatie lijkt daarmee een vruchtbare richting voor verder onderzoek te zijn. De gevonden resultaten bieden verscheidene mogelijkheden voor verder onderzoek. In de eerste plaats is de verhouding tussen gerelateerde en ongerelateerde diversificatie per beheersstructuur niet duidelijk. De indruk bestaat dat coöperaties in vergelijking tot vennootschappen relatief meer lijken te diversificeren in ongerelateerde dan in gerelateerde bedrijfstakken. Dit verschil is met de huidige steekproef niet statistisch significant aan te tonen.

In de tweede plaats geven de bovenstaande resultaten niet noodzakelijk aan dat coöperaties minder efficiënt/winstgevend zijn dan vennootschappen. Empirisch is weliswaar vastgesteld dat het diversificatiegedrag in de beheersstructuren coöperatie en vennootschap significant verschilt, maar de relatie met efficiëntie is niet zonder meer duidelijk. De meta-studie van Palich, Cardinal en Miller (2000) rapporteert een omgekeerd U-vormig verband tussen diversificatie en winstgevendheid. Het 'horizonprobleem' zou kunnen inhouden dat coöperaties een hogere ROI voor nieuwe activiteiten hanteren dan een vennootschap. De diversificatiestrategie van de coöperatie zou zich derhalve meer in het midden kunnen bevinden van het omgekeerde U-vormige verband dan de vennootschap. Het 'horizonprobleem' zou er echter ook toe kunnen leiden dat nieuwe activiteiten die pas op de lange termijn veel gaan opleveren, niet worden ondernomen. Daarnaast zou de investeringskeuze van de coöperatie minder efficiënt kunnen zijn, omdat de leden ook overwegingen inzake het rendement op de investeringen op de boerderij bij hun beslissing betrekken. De indruk bestaat dat deze laatste twee effecten overheersen. De data om deze hypothese te toetsen zijn niet beschikbaar.

Een derde richting voor verder onderzoek is de impliciete veronderstelling in de specificatie van de regressievergelijkingen dat de beheersstructuur de exogene variabele is en de diversificatiestrategie de endogene variabele. Dit is in lijn met onvolledigecontracten-theorie en transactiekosten-economie, waar de keuze van beheersstructuur voorafgaat aan investeringsbeslissingen. Het diversificatiebeleid zou echter wel eens bepalend kunnen zijn voor de keuze van beheersstructuur. Dit zou in lijn zijn met het resultaat 'Form follows function' in de evolutionaire biologie (Cosmides en Tooby, 1994) en de claim van Chandler (1962) 'structure follows strategy', alhoewel deze laatste claim meer betrekking heeft op de interne structuur ten aanzien van divisies en functionele afdelingen dan op de beheersstructuur van de onderneming.

\section{LITERAT U UR}

Amit, R. en J. Livnat, (1988), Diversification strategies, business cycles and economic performance, Strategic Management Journal, 9, pp. 99-110.

Bonin, J.P., D.C. Jones en L. Putterman, (1993), Theoretical and empirical studies of producer cooperatives, Journal of Economic Literature, 31 , pp. 1290-1320.

Chandler, A.D., (1962), Strategy and Structure, MIT Press, Cambridge (MA).

Chatterjee, S. en B. Wernerfelt, (1991), The link between resources and type of diversification: theory and evidence, Strategic Management Journal, 12, pp. 33-48.

Cosmides, L. en J. Tooby, (1994), Better than rational: evolutionary psychology and the invisible hand, 
American Economic Review, 84, pp. 327-332.

Hansmann, H., (1996), The ownership of enterprise, The Belknap Press of Harvard University Press, Cambridge (MA).

Hendrikse, G.W.J., (1998), Screening, competition and the choice of marketing cooperative as an organizational form, Journal of Agricultural Economics, 49, pp. 202-217.

Hendrikse G.W.J. en W.J.J. Bijman, (2001, forthcoming), Ownership structure in agrofood chains: the marketing cooperative, American Journal of Agricultural Economics.

Hendrikse G.W.J. en C.P. Veerman, (1997), Marketing cooperatives as a system of attributes, in: G. van Dijk en J. Nilsson (editors), Strategies and structures in the agro-food industries, Van Gorcum, Assen.

Hendrikse, G.W.J. en C.P. Veerman, (2001a, forthcoming), Marketing cooperatives and financial structure: a transaction costs analysis, Agricultural Economics.

Hendrikse G.W.J. en C.P. Veerman, (2001b), Marketing cooperatives: an incomplete contracting perspective, Journal of Agricultural Economics, 52 (1), pp.53-64.

Hoskisson, R.E. en M.A. Hitt, (1990), Antecedents and performance outcomes of diversification: A review and critique of theoretical perspectives, Journal of Management, 16, pp. 461-509.

Jacquemin, A.P. en C.H. Berry, (1979), Entropy measure of diversification and corporate growth, The Journal of Industrial Economics, 27, pp. 359-369.

Jensen, M.C., (1986), Agency costs of free cash flow, corporate finance, and takeovers, American Economic Review, 76, pp. 323-329.

Jones, G.R. en C.W.L. Hill, (1988), Transaction cost analysis of strategy-structure choice, Strategic Management Journal, 9, pp. 159-172.

Kamers van Koophandel Noord-Brabant, (1995), Tilburg: Informatie over adresbestanden en activiteitencodes.

Kamshad, K.M., (1994), Firm growth and survival: does ownership structure matter? Journal of Economics and Management Strategy, 3, pp. 521543.

Lins, K. en H. Servaes, (1999), International evidence on the value of corporate diversification, Journal of Finance, 54, pp. 2215-2239.

Lubatkin, M., H. Merchant en N. Srinivasin, (1993), Construct validity of some unweighted productcount diversification measures, Strategic Management Journal, 14, pp. 433-449.

Montgomery, C.A., (1994), Corporate diversification, Journal of Economic Perspectives, 8, pp. 163-178.

Nayyar, P.R., (1993), Performance effects of information asymmetry and economies of scope in diversified service firms, Academy of Management Journal, 36, pp. 28-57.

Oijen, van, A.A.C.J., (1997), Besturing door het hoofdkantoor en diversificatie, Van Oijen, Heusden.

Palepu, K., (1985), Diversification strategy, profit performance and the entropy measure, Strategic Management Journal, 6, pp. 239-255.

Palich, L.E., L.B. Cardinal en C.C. Miller, (2000), Curvilinearity in the diversification-performance linkage: an examination of over three decades of research, Strategic Management Journal, 21, pp. 155-174.

Pattison, D., (2000), Agricultural cooperatives in selected transitional countries, Http://www.agricoop.org/resources/resources.htm.

Penrose, E.T., (1959), The theory of the growth of the firm, Blackwell, Oxford.

Peteraf, M.A., (1993), The cornerstones of competitive advantage: a resource-based view, Strategic Management Journal, 14, pp. 179-191.

Pitts, R.A. en H.D. Hopkins, (1982), Firm diversity: conceptualization and measurement, Academy of Management Review, 7, pp. 620-629.

Porter, M.E., (1985), Competitive advantage: creating and sustaining superior performance, The Free Press, New York.

Prahalad, C.K. en R.A. Bettis, (1986), The dominant logic: A new linkage between diversity and performance, Strategic Management Journal, 7, pp. 485-501.

Ramanujam, V. en P. Varadarajan, (1989), Research on corporate diversification: A synthesis, Strategic Management Journal, 10, pp. 523-551.

Rumelt, R.P., (1974), Strategy, structure, and economic performance, Harvard Business School Press, Boston (MA).

Teece, D.J., (1982), Towards an economic theory of the multiproduct firm, Journal of Economic Behavior and Organization, 3, pp. 39-63.

Tosi, H.L. en L.R. Gomez-Mejia, (1989), The decoupling of CEO pay and performance: an agency theory perspective, Administrative Science Quarterly, 34, pp. 169-189.

Varadarajan, P. en V. Ramanujam, (1987), Diversification and performance: a reexamination using a new two-dimensional conceptualization of diversity in firms, Academy of Management Journal, 30, pp. 380-393.

Venkatraman, N., (1989), The concept of fit in strategy research: toward verbal and statistical correspondence, Academy of Management Review, 14, pp. 423-444.

Williamson, O.E., (1975), Markets and hierarchies: analysis and antitrust implications, The Free Press, New York.

Wood, A., (1971), Diversification, merger and research expenditures: a review of empirical studies, in: R. Morris en A. Wood (eds.), The corporate economy: growth, competition, and innovation potential, Harvard University Press, Cambridge (MA). 